\title{
Analysis of Free Indirect Discourse Narratives in the Works of Austen, Joyce, and Kingston
}

\author{
Lestari Manggong \\ Lestari.manggong@unpad.ac.id \\ English Studies Program, Universitas Padjadjaran
}

\begin{abstract}
Language, with the complexity of its structure, can be problematic in terms of interpreting works of literature. This essay discusses the problems perceived in the process of interpretation of free indirect discourse narratives in Jane Austen's Pride and Prejudice and Emma, James Joyce's A Portrait of an Artist as a Young Man and The Dead, and Maxine Hong Kingston's Tripmaster Monkey. Narratives with free indirect discourse opens up possibility of misinterpretation caused by the misconception of whose point of view the story is told. By looking at the works within the concept of narratology by Chatman (1978) and Prince (2003), such narratives-which apply the viewpoint of omniscient narrators - cause ambiguity to the voice of external and internal focalisers. This is due to the fact that the use of such narratives blends the two types of focalisations. The findings of this research lead to an argument that through external focalisation, the view becomes objective. Yet through internal focalisation, the view tends to become subjective as it is infiltrated by the character's view. Such an argument then gives way to a conclusion that narratives with free indirect discourse gives effect to irony in the story-telling process of the works discussed.
\end{abstract}

Keywords: free indirect discourse, narratology, focalisation

\section{Introduction}

Narratives with free indirect discourse open the possibility of misinterpretation caused by the misconception of whose point of view the story is told. Such narratives that employ the narrative technique using omniscient narrator cause the voice of both external and internal focaliser to become ambiguous as the use of such narratives blur the two. Through external focaliser, the view presented tends to become objective. Through internal focaliser, the view presented tends to become subjective, since it is infiltrated by the character's perception. This essay discusses the problems occurred in the process of interpretation of narratives with free indirect discourse in the works of Austen (Emma and Pride and Prejudice),
Joyce (A Portrait of an Artist as a Young Man and the Dead), and Kingston (Tripmaster Monkey). At the end of the discussion, this essay shows what factors unveil the aspect of irony in the story, as the effect of such narratives in the novels.

\section{Analysis of Narratives with Free Indirect Discourse}

Detailed observations on narratives with free indirect discourse have been conducted by Johnson (2000) on his Introduction to Joyce's novel, $A$ Portrait of the Artist as a Young Man (further called $A$ Portrait). They open new perspectives on the importance of misinterpretation on 
fictional prosaic works that use free indirect discourse. In his observation, Johnson (2000) compares the use of free indirect discourse in $A$ Portrait with one of Jane Austen's novels, Emma. The following part shows how the use of free indirect discourse can potentially mislead the perception on from whose point of view the story is told. This eventually will mislead the reader's interpretive understanding of the story. The examples presented by Johnson are scenes taken from Volume II Chapter 12, when Mr. Knightley and Emma are both in the same room:

He stopped again, rose again, and seemed quite embarrassed. He was more in love with her than Emma had supposed; and who can say how it might have ended if his father had not made his appearance? (Austen, 1964: 206-7)

Johnson sees that this part in a glance looks as if it is coming from an objective observation of an omniscient narrator. Yet, if we take a closer look, we can see that the narrator here presents Emma's assumption. In relation to this, in order to understand why it is so, one can rationalise that if this part is not read closely it is as if the point of view used is external focalisation, since what is described is the gestures of the sentence's subject (he/Mr. Knightley). The first sentence does show that: the lens of the objective camera eyes of the external focaliser describes Mr. Knightley's gestures ('stopped' and 'rose') and also Mr. Knightley's expression ('seemed quite embarrassed'). The next sentence is not descriptive because it contains the narrator's piece of mind. The first clause of this sentence is infiltrated with the narrator's subjective opinion ('He was more in love with her than Emma had supposed; and who can say how it might have ended if his father had not made his appearance?'). Since this sentence is put right after the sentence before that uses external focalisation which contains the narrator's objectivity, when it is then read simultaneously, the influence of this objectivity still has its effect on the sentence that comes after. This inevitably causes the interpretation of the second sentence to be objective as well.

When the narrator says 'He was more in love with her than Emma had supposed', it potentially builds the reader's assumption that Mr. Knightley has certain romantic interest with Emma. What is neglected here is the fact that what is said in this sentence is-as mentioned earlier-the narrator's subjective opinion, as the result of concluding Mr. Knightley's awkward gestures, which is the result of Emma's presence in the room. The rhetorical question that comes after this ('and who can say how it might have ended if his father had not made his appearance?') opens up a space of expectation in the mind of the readers. If Mr. Knightley's awkward gestures which reflects his romantic interest towards Emma is not interrupted by the presence of Emma's father afterwards, then there is great potential that such a reflection of $\mathrm{Mr}$. Knightley's gestures will give result to an action that actualises such a romantic interest. In my view, such a narrative technique is strategically capable of manipulating the reader's interpretation. The manipulation is seen when the expectation which most probably occurs in the reader's mind is capable of causing the reader to cling on the hope that the real action of Mr. Knightley's supposedly romantic interest towards Emma could happen in the next segment of the plot.

Chatman (2003) reviews the use of free indirect discourse (which he termed as the synonym of interior monologue) in another of Jane Austen's work, Pride and Prejudice. His observation falls on the narrative chunk at the beginning of Chapter 57, not long after Lady Catherine (Mr. Darcy's aunt, the man Elizabeth Bennet-the main character of this novel-is interested in) leaves the Bennets residence to clarify an issue she hears about the engagement of her nephew with Elizabeth:

The discomposure of spirits which this extraordinary visit threw Elizabeth into could not be easily overcome, nor could she for many hours learn to think of it 
less than incessantly. Lady Catherine, it appeared, had actually taken the trouble of this journey from Rossings for the sole purpose of breaking off her supposed engagement with Mr. Darcy. It was a rational scheme, to be sure! But from what the report of their engagement could originate, Elizabeth was at a loss to imagine; till she recollected that his being the intimate friend of Bingley, and her being the sister of Jane, was enough, at a time when the expectation of one wedding made everybody eager for another, to supply the idea. She had not herself forgotten to feel that the marriage of her sister must bring them more frequently together. And her neighbours at Lucas Lodge, therefore (for through their communication with the Collinses the report, she concluded, had reached Lady Catherine), had only set that down as almost certain and immediate, which she had looked forward to as possible, at some future time (Austen, 1994: 277).

This narrative is important because according to Chatman it is at this moment that Elizabeth's bewilderment, high hope, and anger is reflected. In the narrative we can see that:

1) Elizabeth is disturbed by Lady Catherine's arrival,

2) Elizabeth keeps thinking of Lady Catherine's intention to visit her, along the urgency it brings,

3) Elizabeth assumes the reason behind her engagement,

4) Elizabeth speculatively thinks that the reason is because Darcy is Bingley's friend and she is Jane's big sister, who is Bingley's wife, and

5) Elizabeth thinks that the Lucases (her neighbour) through the Collins also take part in shaping the issue up to the point where Lady Catherine finally learns about it.

What is important to be observed here is that such assumption and speculation are inexplicitly mentioned as what is thought by Elizabeth because it does not say anywhere that 'Elizabeth thought.' This raises an interpretation that it is the narrator who is speaking. Thus, the absence of the use of 'Elizabeth thought' blurs both the objectivity and subjectivity of the presupposed assumption and speculation. In other words, at the same time, such views become objective and subjective. Once again, it is this factor that potentially manipulates the reader's thought. The objectivity of the narrative causes the assumption and speculation to become almost like a fact. The use of the verb 'recollected' enables that, while the verb 'had not forgotten to feel' shows that Elizabeth just 'feels' that way.

Johnson (2000), in his observation on the use of free indirect discourse in $A$ Portrait shows that Joyce exploits such a narrative technique, enabling the point of view to shift from Stephen's to the narrator. In the narrative of Emma, Johnson sees that the speaking style of any character revealed is consistent. From here, it can be seen that the style seen in Emma is Austen's. At the beginning of $A$ Portrait, the speaking style starts with the speaking style that is very characteristic of Stephen's. the use of a variety of idiolect in the characters makes Joyce's voice unidentifiable. In other words, different from Austen, Joyce does not put his influence as the writer of the novel. Johnson also observes that the variation of idiolect needs to be included because it represents the development in the growing phase of the 'artist.' The narrative style changes as the 'artist' reaches maturity.

In another one of Joyce's work, in the short story The Dead, Dettmar (1996) focuses on his observation at the end of the story. In his explanation, Dettmar also points out that the narrative discourse in the end does not fall into the category of Chatman's free indirect speech/discourse. He argues that it is because Gabriel Conroy (the main character in the story) is not in the middle of making a statement (verbally or nonverbally) when he is looking out the window. Thus, we cannot say that his statement is being indirectly revealed by the narrator. Because of that, Dettmar proposes a different term, that is, free indirect prose. 
Gabriel is actually doing some thinking at that point in the narration, but it does not mean that the long paragraph in the end is what goes on in Gabriel's thought. The oddity can be seen because the narrative is very well-structured and poetic, as can be seen in the following:

A few light taps upon the pane made him turn to the window. It had begun to snow again. He watched sleepily the flakes, silver and dark, falling obliquely against the lamplight. The time had come for him to set out on his journey westward. Yes, the newspapers were right: snow was general all over Ireland. It was falling on every part of the dark central plain, on the treeless hills, falling softly upon the Bog of Allen and, farther westward, softly falling into the dark lonely churchyard on the hill where Michael Furey lay buried. It lay thickly drifted on the crooked crosses and headstones, on the spears of the little gate, on the barren thorns. His soul swooned slowly as he heard the snow falling faintly through the universe and faintly falling, like the descent of their last end, upon all the living and the dead. (Joyce, 2000: 176)

It is impossible to say that this is a narrative that comes out of Gabriel's mind, because the speech style is different from the speech style he uses in his speech before dinner. Based on this argument, Dettmar calls that the narrative is Gabriel's prose which is plagiarised by the narrator.

The problem in the use of free indirect discourse is also apparent in Tripmaster Monkey by Kingston. Wittman Ah Sing, the main character of the novel, has a list of prejudices towards Chinese, and because of that, he refuses to be identified as Chinese. Throughout the plot, Wittman emphasises that his cultural identity is America; Berkeley graduate with Beatnik looks, having wide range of knowledge in Western literature, with a white girlfriend. The free indirect discourse used in his narrative enables the point of views to move from external to internal focaliser and vice versa. This manuver, once again, can potentially blur Wittman's objective and subjective statement.

In the novel, in my observation, such potency leads to irony. The irony can be seen when Wittman's way of seeing and the narrator's are being compared. In terms of problems in viewpoint presented by omniscient narrator, in an interview Kingston points out that the omniscient narrator in the Tripmaster Monkey is a Chinese American woman; she's Kwan Yin (the Goddess of Mercy) and she's me' (Schueller, 2003: 18). In another interview, Kingston also states: 'Wittman is working against a narrator who is trying to create him from outside' (Jannette, 1996: 146). If the narrator was indeed Kingston a.k.a. Kwan Yin, whose role is to help the Monkey on his journey to the West, then the narrator in Wittman's journey in the West who is present through and outside Wittman's voice shows irony in the narratives as a result of Wittman's prejudice that influence his perception on Chinese ethnicity. An example can be seen in the following part:

Heading toward him from the other end came a Chinese dude from China, hands clasped behind, bow-legged, loose-seated, out on a stroll-that walk they do in kung fu movies when they are full of contentment on a sunny day. As luck would have it, although there was plenty of room, this dude and Wittman tried to pass each other both on the same side, then both on the other, sidestepping like a couple of basketball stars. Wittman stopped dead in his tracks, and shot the dude a direct stink-eye. The F.O.B. stepped aside. Following, straggling, came the poor guy's wife. She was coaxing their kid with sunflower seeds, which she cracked with her gold tooth and held out to him. "Ho sick, la. Ho sick," she said. "Good eating. Good eats." Her voice sang, rang, banged in the echochamber tunnel. Mom and shamblelegged kid were each stuffed inside of about ten homemade sweaters. Their arms stuck out fatly. The mom had on a nylon or rayon pantsuit. ("Ny-lon ge. $\mathrm{Mm}$ lon doc." "Nylon-made. Lasts forever.") 
"No!" said the kid. Echoes of "No!" Next there came scrabbling an old lady with a cane. She also wore one of those do-ityourself pantsuit outfits. On Granny's head was a cap with a pompon that matched everybody's sweaters. The whole family taking a cheap outing on their day offu. Immigrants. Fresho off the Boats out in public. Didn't know how to walk together. Spitting seeds. So uncool. You wouldn't mislike them on sight if their pants weren't so highwater, gym socks white and noticeable. F.O.B. fashions-highwaters or puddlecuffs. Can't get it right. Uncool. Uncool. The tunnel smelled of mothballs-F.O.B perfume.' (Kingston, 1990: 4-5)

As can be seen from this part, in the first sentence, the clause that says: 'Heading toward him from the other end came a Chinese dude from China, hands clasped behind, bow-legged, loose-seated, out on a stroll' is the narrator's external focalisation. It means that it does not infiltrate the character's voice, and as a camera, it presents descriptively what is seen on the lens. The second clause which says: 'that walk they do in kung fu movies when they are full of contentment on a sunny day' provides an analogy to describe the way this Chinese man walks, which is also apparently the narrator's external focalisation which at the same time, can work as the main character's voice (Wittman's). This is so because we can sense the cynicism reflected from the stereotyping of the Chinese walks: 'that walk ... in kung fu movies.' Observed in more detailed manner, without the presence of the second clause, the description of the way the man who does the Chinese walk when he comes across Wittman is already very clear in the first clause. Yet, the second clause is still presented, and the m.o (modus operandi) is the necessity to emphasise the narrator's viewpoint towads the China man.

In the second sentence, by the power of the narrator, Wittman and the Chinese man almost bump into each other and thus try to avoid one another. In the third sentence, Wittman halts and stares at the Chinese man. In the fourth sentence, this Chinese man whom Wittman calls F.O.B (Fresh off the Boat) steps aside. F.O.B. is a term labelled to Chinese immigrants who have just arrived in the U.S.A. It is of importance to notice that the use of the term F.O.B. here is derogatory, considering the person being compared is Wittman, who has stayed longer in the U.S., and thus is far from fit to be called F.O.B. The focalisation of the narrative presented from sentence two to four is also external. Compared with the second clause, the first sentence is loaded with cynicism, whereas the fifth sentence is loaded with negative sentiments (which is obvious from the way Witman says 'the poor guy's wife'). Next, the camera focuses on the wife, describing her stuffing sun flower seeds to her kid's mouth. Along with this, the camera's observation then focuses on the clothes they are wearing. They are wearing 10 layers of sweaters with nylon or rayon fabric. This description also highlights the fact that they are F.O.B.s. After this, the camera's observation moves to an old lady's clothes, which are also the same as the wife and her kid. The next 11 sentences throw cynicism after cynicism about Wittman's observation on the F.O.B.s. The narrator, at this point, no longer has the power to control its narrative, as if Wittman grabs the mike from the narrator. 'Cheap outing,' 'So uncool,' Wittman repeatedly says. What is important here is that in the text, Wittman's voice does not transition into a direct speech, but it becomes an indirect one, since he is still in the narrator's domain.

A more complex issue on the mix between external and internal focalisation is seen at another part of the novel, when the narrative very explicitly shows that the focalisers are both the narrator and Wittman:

Out on the streets, Wittman fitted onto his Mongolian cheeks his spectacles that blurred everything, thus finding metaphors everywhere, like how a cable car looks like an animal-cracker box. Some things he couldn't tell what the fuck they were, so he'd go up to a bedevilment and have a look-see, not to miss out. Like Rimbaud, I practice having hallucinations' (Kingston: 44). 
We can see from this part that in one domain, Wittman is present as both third person singular (he) and first person singular (I). Logically, the second sentence of this part can be understood as the result of the first sentence. The second sentence which shows the narrator's internal focalisation over Wittman is in itself constructs Wittman's opinion, or it can also be understood as a declaration that underlines the fact that because he uses special glasses, he can see things other people cannot see.

The shift from subject 'he' to 'I' illustrates that Wittman's statement is constructed by the narrator. This indicates that Wittman's identity is a construct of some exterior force, that is, the narrator's. But what is problematic here is that because Wittman's voice is textually non-present in direct speech and thus creates no demarcation between the narrative voice of third and first person singular, then what is seen is that both voices collide. If perceived this way, then the voice of third person singular at the same time constructs the voice of first person singular. This leads us to conclude that when Wittman says 'Like Rimbaud, I practice having hallucinations,' Wittman is in the process of trying to comprehend what he is going through, as presented by the narrator.

\section{Conclusion: Irony in the Works with Free Indirect Discourse Narrative}

Based on the observation of two of Austen's works, I conclude that Johnson's (2000) Chatman's (1978) findings on Emma and Pride and Prejudice shows that the use of free indirect discourse causes the narrative to experience an extrapolation, meaning that the facts supposedly known at the beginning is used to draw conclusion about unclear matter. Extrapolation can also be understood as a construction on judgment or opinion which does not have conclusive information. In Emma, extrapolation builds the reader's expectation, making the reader hope that Mr. Knightley is indeed attracted romantically to Emma. The facts in the narrative only indicate that Mr. Knightley's awkward gesture is interpreted by the narrator as a gesture that shows his interest on Emma. In Chatman's (1978) finding, such extrapolation builds speculation on the series of causes that trigger Mr. Darcy's engagement with Elizabeth. The speculation built on the facts which are merely Elizabeth's guesses potentially shapes a perception that that is actually how the enjoyment comes to its form. The effects of such extrapolation reveals the irony seen when the proofs that is presented as facts are just assumption.

In Dettmar's (1996) review on The Dead, the irony is also apparent due to the use of free indirect discourse narrative. Irony is present on the gap between Gabriel's utterance and the narrator's. In Tripmaster Monkey, internal focalisation used mediates Wittman's cynicism towards Chinese ethnicity. It also provides space for Wittman to avoid himself from being stereotyped as Chinese. Overall, the series of stereotyping of Chinese ethnicity is Wittman's critical view on multicultural America. We can irony whenever Wittman is avoiding being identified as Chinese, because it is at that moment the contrast between two cultural identities (Chinese and American) are juxtaposed and compared.

\section{References}

Austen, Jane. Emma. New York: The New American Library, 1964.

Chatman, Seymour. Story and Discourse: Narrative Structure in Fiction and Film. New York: Cornell University Press. 1978.

Dettmar, Kevin J. H. The Illicit Joyce of Postmodernism: Reading against the Grain. Wisconsin: The University of Wisconsin Press. 1996. 
Janette, Michele. "The Angle We're Joined at." Transition. Issue 71, 1996: 142-157.

Joyce, James. A Portrait of the Artist as a Young Man (Edited and Introduced by Jeri Johnson). Oxford: Oxford University Pres. 2000.

Dubliners (Edited and Introduced by Jeri Johnson). Oxford: Oxford University Pres. 2000.

Kingston, Maxine Hong. Tripmaster Monkey: His Fake Book. New York: Vintage International. 1990.

Prince, Gerald. Dictionary of Narratology (Revised Edition). Lincoln and London: University of Nebraska Press. 2003.

Schueller, Malini Johar. "Theorizing Ethnicity and Subjectivity: Maxine Hong Kingston's Tripmaster Monkey and Amy Tan's The Joy Luck Club." Modern Critical Interpretations: Amy Tan's The Joy Luck Club. Harold Bloom (Ed.). Philadelphia: Chelsea House Publisher, 2003. 